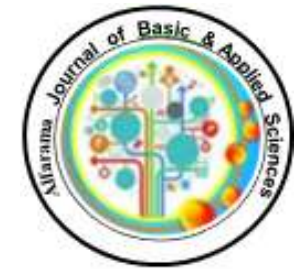

ISSN 2682-275X
Alfarama Journal of Basic \& Applied Sciences

Faculty of Science Port Said University https://ajbas.journals.ekb.eg

ajbas@sci.psu.edu.eg

http://sci.psu.edu.eg/en/

July 2020, Volume 1, Issue 2

DOI:10.21608/AJBAS.2020.21978.1006

Submitted: 09-01-2020

Accepted: 12-04-2020

Pages: 78-89

\title{
Screening and Molecular Characterization of Cellulase Producing Thermophilic Bacteria Isolated from an Egyptian Hot Spring in Ras-Sedr
}

\author{
Maii Elsharayidi ${ }^{1, *}$, Ahmed Dewedar, ${ }^{2,}$ Hesham shafik ${ }^{1}$ and Walid Elkazzaz ${ }^{2}$. \\ ${ }^{1}$ Botany Department, Faculty of Science, Port-Said University, Port-Said, Egypt. \\ ${ }^{2}$ Botany Department, Faculty of Science, Suez Canal University, Ismailia, Egypt \\ * Corresponding author email: maiisaleh0@gmail.com
}

\begin{abstract}
This research was carried out to screen and characterize the rmophilic bacteria that have the ability to produce cellulase enzyme. Bacterial strains were isolated from the sediment samples collected from Ras-Sedr's hot spring located in Ras-Sedr, Egypt. For cellulolytic activity testing, Carboxymethylcellulose (CMC) agar was used as growth medium. Seven bacterial isolates showed variable zones of CMC clearance. Evaluation of cellulase enzyme thermal activity was carried out at varying temperatures from $35^{\circ} \mathrm{C}$ to $85^{\circ} \mathrm{C}$ and the impact of $\mathrm{pH}$ on cellulase activity was evaluated at different $\mathrm{pH}$ levels of 59. Molecular identification for the isolates also conducted based on 16S rRNA gene sequencing. At $55^{\circ} \mathrm{C}$ and $\mathrm{pH} \mathrm{7,} \mathrm{all} \mathrm{the} \mathrm{seven} \mathrm{bacterial} \mathrm{isolates} \mathrm{showed} \mathrm{their} \mathrm{optimum}$ growth conditions. Strains were gram positive, have rod shape cells, spore forming and motile with the ability to produce thermostable cellulase. The results of the phylogenetic analysis reveal a high degree of sequence similarity between the isolated bacteria involved in this research and Geobacillus sp. These thermophiles have the ability to produce useful thermostable cellulase enzyme of industrial significance, which in turn indicates that RasSedr's hot spring considered a prospective source of economically significant microorganisms which needs more studies through further researches.
\end{abstract}

\section{Keywords}

Hot Springs - Thermophilic Bacteria- Cellulase - 16S rRNA.

\section{INTRODUCTION}

Since the development of the polymerase chain reaction, the enzymes of extreme thermophiles have been of significant concern in biotechnology [1]. It is not surprising, given the usefulness of thermostable enzymes in molecular biological laboratory techniques, that they were also suggested as strong resources for industrial catalysis [30]. The challenge of thermal inactivation of the enzyme is commonly reported in 
industrial applications where enzymes are applied [26]. For industrial uses, therefore, enzyme stability is a key factor.

Thermophilic bacteria are major sources of thermostable enzymes, and their suitable habitats are typically geothermal conditions such as hot springs [20]. Hot springs are described as natural thermal spots generated by groundwater with geothermal heating. Geothermal springs are often highly energetic environments not only because temperatures can reach the boiling point, but also because their waters are often charged with elevated sulfur levels. They contain microorganism populations that may be a source of significant bioactive compounds such as thermostable enzymes [24]. Because of their broad applications, cellulases have attracted a lot of interest. Together with agriculture and other research purposes, cellulases are critical in fruit, beverage and wine, textile, paper and pulp industries [5, 12]. In this work, an effort was made to screen bacterial isolates from hot spring of Ras- Sedr that produce cellulase enzyme. Cellulase characterization based on $\mathrm{pH}$ and temperature was performed then followed by molecular characterization of the isolates based on16s rRNA.

\section{MATERIALS AND METHODS}

\subsection{Source of Microorganisms}

Sediment samples from the hot spring were gathered. Hot spring located in Egypt, Ras -Sedr, Abo Swira, El Mahager road (Figure 1). Sediment samples were collected during summer season (May-June) in $1000 \mathrm{ml}$ bottles of sterile Pyrex using sterile glass flasks and were maintained on ice until processing. Upon arrival at the University of Suez Canal, all samples were immediately stored at $4{ }^{\circ} \mathrm{C}$; sediment samples were subjected within $24 \mathrm{~h}$ to chemical analysis and cellulase screening.

\subsection{Cellulolytic Activity Assessment:}

For cellulolytic activity testing, Carboxymethylcellulose (CMC) agar according to [3] was used as growth medium. Cultivation medium containing: $0.1 \mathrm{~g}$ of calcium chloride dehydrate $\left(\mathrm{CaCl}_{2} \cdot 2 \mathrm{H}_{2} \mathrm{O}\right), 5.0 \mathrm{~g}$ of sodium chloride, and $10.0 \mathrm{~g}$ of peptone, $2.0 \mathrm{~g}$ of $\mathrm{CMC}$ and $20.0 \mathrm{~g}$ of agar. With the addition of $1 \mathrm{M} \mathrm{NaOH}$, the $\mathrm{pH}$ of medium was set to 7.0. First, sediment sample were enriched by adding $90 \mathrm{ml}$ of $0.9 \% \mathrm{NaCl}$ saline solution to $10 \mathrm{gm}$ sediments in $250 \mathrm{ml}$ Erlenmeyer flask with shaking at $300 \mathrm{rpm}$ for $1 \mathrm{~h}$ at $55^{\circ} \mathrm{C}$. Then, one $\mathrm{ml}$ of sediment extract was poured to the sterile Petri- dishes. Triplicate set of sample was used and the plates were wrapped with parafilm and kept for $24-48 \mathrm{~h}$ of incubation at $55^{\circ} \mathrm{C}$ in clean plastic bags. The resulting colonies were streaked on CMC plates and incubated for $24-48 \mathrm{~h}$ at $55^{\circ} \mathrm{C}$. Gram's iodine was used as indicator and the development of halo zones proved positive activity of CMC hydrolysis.

\subsection{Morphological \& Biochemical Test:}

Cell colony morphology and Gram reaction were investigated according to the method described by [10]. Spore formation was examined according to the method described by [6]. Some biochemical and physiological tests were performed using the method of [9].

\subsection{Assessment of isolates growth pattern:}

The temperature range for growth was determined using a protocol described by [28]. Inoculated in $50 \mathrm{ml}$ 


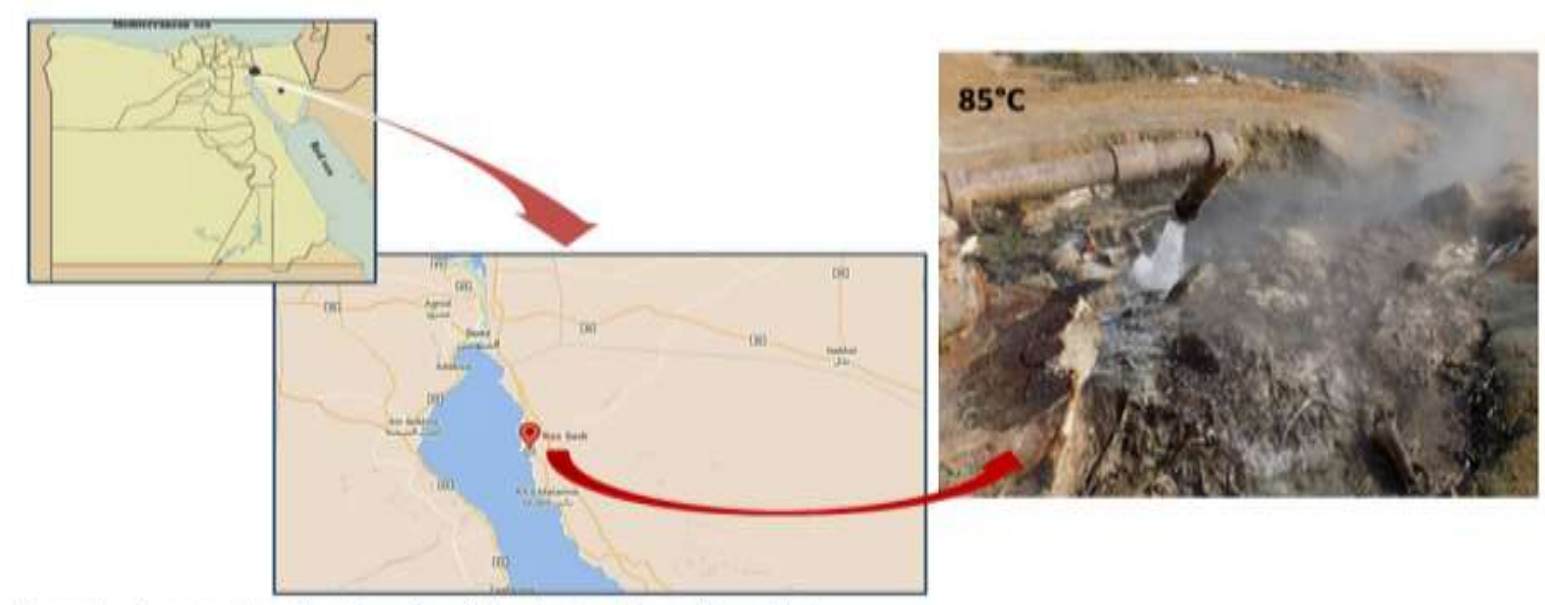

Figure 1: A map showing the site of the hot spring of Ras-Sedr.

nutrient broth (NB) media, the isolates were incubated for 24 hours. Quantities of broth cultures were adapted to obtain similar optical density (OD) at $600 \mathrm{~nm}$ with the addition of sterile water. In $100 \mathrm{ml} \mathrm{NB}$ media, a volume of $0.1 \mathrm{ml}$ from each bacterial isolates was incubated at $182 \mathrm{rpm}$ at $35^{\circ} \mathrm{C}, 45^{\circ} \mathrm{C}, 55^{\circ} \mathrm{C}$ as well as $65^{\circ} \mathrm{C}$ separately in the shaker. For each culture, three replicate flasks of $100 \mathrm{ml}$ capacity were maintained. In a spectrum of $600 \mathrm{~nm}$, the OD of isolates was obtained by measuring around $3 \mathrm{ml}$ of isolates at intervals of 4 hours. In the same manner, growth $\mathrm{pH}$ dependency was tested at $\mathrm{pH}$ levels between 5 and 9. Acetate buffer (for $\mathrm{pH} 5.0$ ), sodium phosphate buffer (for $\mathrm{pH} 6.0$ and 7.0) and Tris Buffer (for $\mathrm{pH}$ 8.0 and 9.0) were the used buffers at concentration $0.1 \mathrm{M}$ to evaluate the optimum $\mathrm{pH}$.

\subsection{Isolation of extracellular cellulase enzyme:}

In order to obtaining the crude cellulase, the isolate with the maximum hydrolysis zone was grown in an environmental shaker with the addition of $100 \mathrm{ml}$ of CMC broth at $170 \mathrm{rpm}$ and $55^{\circ} \mathrm{C}$. At $10,000 \mathrm{rpm}$ $\mathrm{CMC}$ broth was centrifuged for $10 \mathrm{~min}$ at $4^{\circ} \mathrm{C}$. Cell debris was collected as pellets and the supernatant which contains the crude cellulase enzyme was collected. Supernatants were then filtered using pore size membrane $0.45 \mu \mathrm{m}$ at $4^{\circ} \mathrm{C}$, a method described by [23]. The resulting crude cellulase enzyme was used to assess the effect of temperature and $\mathrm{pH}$ on the activity of the enzyme.

\subsection{Effect of Temperature and $\mathrm{pH}$ on the Activity of Cellulase:}

The relative activity of cellulase at different $\mathrm{pH}$ and temperatures was measured by DNS (3, 5dinitrosalicylic acid) method by measuring the quantity of reducing sugar produced during hydrolysis [15].The optimum temperature for the activity of the crude cellulase enzyme was determined by incubating the enzyme separately at different temperatures ranging from $35^{\circ} \mathrm{C}$ to $85^{\circ} \mathrm{C}$ for $30 \mathrm{~min}$. One hundred microliters of crude cellulase was added to one hundred milliliter of CMC (1\%) as a substrate of the enzyme on Tris-HCl $50 \mathrm{mM}(\mathrm{pH} \mathrm{7)}$. Finally, the optical density was measured at $540 \mathrm{~nm}$. For the assessment of enzyme stability under various degrees of temperatures, the crude cellulase enzyme was kept for an hour separately at temperatures ranging from $35^{\circ} \mathrm{C}$ to $85^{\circ} \mathrm{C}$ for an hour and the optical density was measured at $540 \mathrm{~nm}$.

The assessment of the $\mathrm{pH}$ optimum for the enzyme activity was done by incubating the enzyme for $30 \mathrm{~min}$ at a temperature of $55^{\circ} \mathrm{C}$ in $\mathrm{pH}$ in between 5.0 to 9.0. One hundred microliters of cellulase was added to one hundred milliliter of $\mathrm{CMC}(1 \%)$ as the substrate of the enzyme with the addition of various buffers, separately. $50 \mathrm{mM}$ of each of acetate, phosphate, Tris- $\mathrm{HCl}$ and glycine buffer was used to obtain $\mathrm{pH} 5, \mathrm{pH}$ 6-7, $\mathrm{pH} 8$ and $\mathrm{pH} 9$ respectively. The assessment of enzyme stability under various degrees of $\mathrm{pH}$ was determined by mixing one hundred microliters of crude cellulase separately with the previously mentioned buffers for an hour at $55^{\circ} \mathrm{C}$; finally the optical density was measured at $540 \mathrm{~nm}$. 
Each experiment was done in triplicate and the mean value for each experiment was calculated.

\subsection{DNA extraction, PCR amplification \& molecular identification:}

Genomic DNA was extracted according to protocol described by [21] with slight modifications. $1 \mathrm{ml}$ of an overnight culture was transferred to an Eppendorf tube; cells were harvested and resuspended in $400 \mu 1$ saline-EDTA. Cells were incubated at $60^{\circ} \mathrm{C}$ for $15 \mathrm{~min}$ after the addition of $10 \mu \mathrm{l}$ of lysozyme $(0.1 \mathrm{mg} /$ $\mathrm{ml})$. Eventually, cells were lysed by adding $10 \mu \mathrm{l}$ of proteinase $\mathrm{K}(1.0 \% \mathrm{w} / \mathrm{v})$ and $10 \mu \mathrm{l}$ of SDS (25\%). Using equal amounts of phenol, phenol-chloroform, and crude DNA was extracted. Nucleic acids were precipitated with isopropyl alcohol washed with 70\% ethanol, dried and dissolved TE buffer. Spectrophometrically, the concentration of DNA was determined. For 16S rRNA identification, the universal bacterial primers 27F (5'-AGTTTGATCCTGGCTCAG-3') and 1492R (5'GGTTACCTTGTTACGACTT-3') was used for PCR. With the addition of fifty microliter of the reaction combination, the PCR was carried out with the next circumstances the former denaturation was performed at $95{ }^{\circ} \mathrm{C}$ for 4 minutes followed by denaturation at $94{ }^{\circ} \mathrm{C}$ for 30 seconds then the annealing stage at $55{ }^{\circ} \mathrm{C}$ for 30 second and the extension at $72{ }^{\circ} \mathrm{C}$ for 90 seconds finally the extension at $72{ }^{\circ} \mathrm{C}$ for 7 minutes. PCR product $(50 \mathrm{ng} / \mu \mathrm{l})$ of each isolate was used to prepare the samples which were delivered to MacroGen Company in Korea following their specifications. The sequence similarity search was conducted with Basic Local Alignment Search Tool (BLAST) of the National Center of Biotechnology Information (NCBI) on the following site http:/blast.ncbi.nlm.nih.gov/Blast.cgi to estimate the degree of similarity for the seven isolates in the Genebank. In the BLAST database tracking program, the phylogenetic tree was constructed using the 16S-rRNA sequence of other bacteria using MEGA Molecular Evolutionary Genetics Analysis software version 10. https://www.megasoftware.net/

\section{RESULTS AND DISCUSSION}

Samples of the sediment were obtained from hot spring in egypt, ras sedr, abo swira, el mahager road. The temperature of the sediment in the site recorded to be $85^{\circ} \mathrm{c}$ and 7.09 for $\mathrm{ph}$. The texture of the sediments were sandy loamy and the concentration of the organic matter was $2.615 \%$ with different anions, cations and heavy metals composition listed in (Table 1).

The quantity of cellulose consumed by soil microbes as a main source of carbon depends on abiotic conditions such as organic matter, ph and soil temperature. The sediment analysis showed that the organic matter content in sediment sample was $2.625 \%$. According to [32] cellulose is the principal mass of organic matter that is degraded by soil microorganisms completely or partially. Another factor can affect the activity of cellulase is ph of the sample. In this study, the ph was 7.09; [33] detected high cellulase activity and stability in the range of neutral and alkaline phs. The main action of cellulase enzyme is deconstruction of cellulose, which has highly ordered structure, and it represents the most important challenges in biotechnology. It worth mentioning that, [34] discussed the positive effect of anions/cations in deconstruction of cellulose polymers. He found that anions/cations controlling the dissolution process which is an important step before conversion of cellulose. In this study, chemical analysis of sediments showed the presence of anions such as $\mathrm{hco}_{3}{ }^{-}-\mathrm{SO}_{4}{ }^{2-}-\mathrm{Co}_{3}{ }^{2-}$ and cations such as $\mathrm{mg}^{2+}-\mathrm{na}^{+}$ $-\mathrm{k}^{+}$.

A maximum of twenty organisms those have the ability to grow on the agar plates of the cmc were isolated, but only seven thermophillic bacteria have been successfully isolated with the ability to use carboxymethylcellulase $(\mathrm{cmc})$ as their primary source of carbon. Isolates were gram positive, have rod shape cells, spore forming and motile bacteria with the ability to produce acid from glucose, fructose, maltose and mannose. Other differentiations in phenotypic characterizations illustrated on Table 2 
Table (1). Analysis of sediment sample.

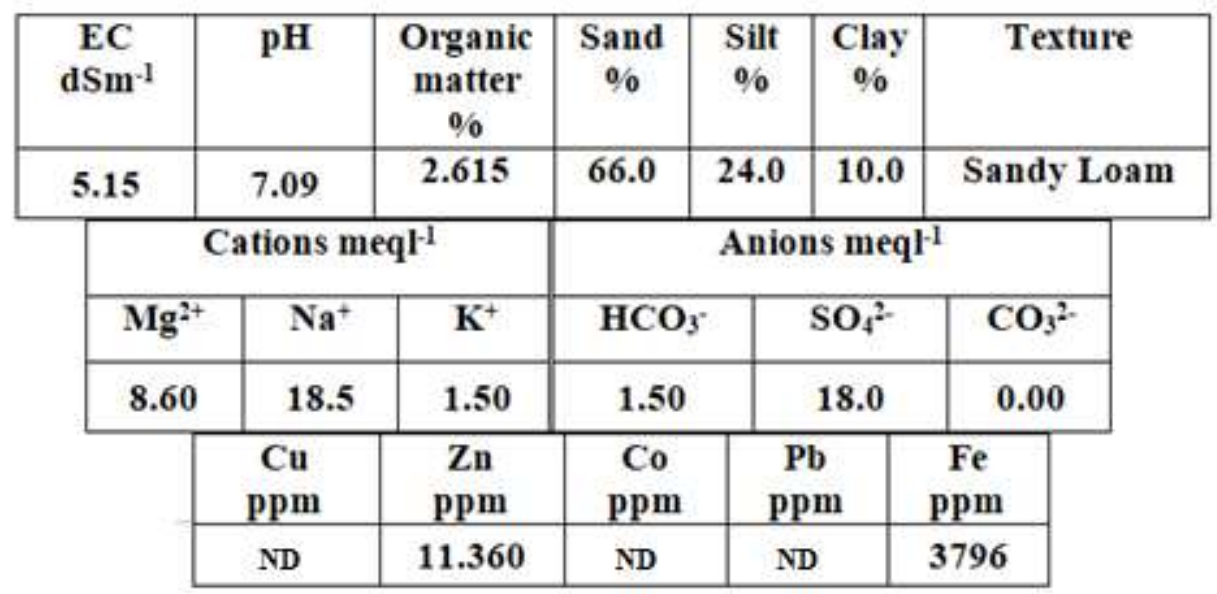

(Table 2): Phenotypic characterization of isolated strains.

\begin{tabular}{|l|c|c|c|c|c|c|c|}
\hline \multirow{2}{*}{ Characteristic } & \multicolumn{7}{|c|}{ Strain code } \\
\cline { 2 - 9 } & HRS1 & HRS12 & HRS13 & HRS14 & HRS5 & HRS6 & HRS7 \\
\hline Pigmentation & off-white & creamy & off-white & off-white & beige & creamy & creamy \\
\hline Colony size (mm) & 1.5 & 1 & 1 & 2 & 1.5 & 1.5 & 2 \\
\hline Colony elevation & flat & flat & flat & convex & raised & convex & raised \\
\hline Colony appearance & shiny & shiny & shiny & shiny & shiny & shiny & shiny \\
\hline Cell shape & rod & rod & rod & rod & rod & rod & rod \\
\hline Spore formation & + & + & + & + & + & + & + \\
\hline Motile & + & + & + & + & + & + & + \\
\hline Gram reaction & + & + & + & + & + & + & + \\
\hline Casein hydrolysis & - & - & - & + & - & - & + \\
\hline Acid from glucose & + & + & + & + & + & + & + \\
\hline Acid from fructose & + & + & + & + & + & + & + \\
\hline Acid from maltose & + & + & + & + & + & + & + \\
\hline Acid from ribose & - & + & + & - & - & - & + \\
\hline Acid from mannose & + & + & + & + & + & + & + \\
\hline Nitrate reduction & - & - & - & - & + & + & + \\
\hline Voges-Proskauer & - & + & - & + & + & + & - \\
\hline Catalase & + & + & - & + & + & + & + \\
\hline Oxidaes & - & - & + & - & - & - & + \\
\hline
\end{tabular}

Such isolates developed $\mathrm{cmc}$ clearance variable zones in the presence of iodine solution staining figure 2 . $[14,18]$ performed a similar experiment for screening and identification of cellulase producing bacteria, which found the iodine solution to be quick and effective in detecting many positive cellulase producing bacteria from broad range of samples. [17] also used cmc agar plates and iodine solution staining to evaluate cellulase producing bacteria from hot spring.

The temperature range for growth was determined by incubating the isolates separately in $35^{\circ} \mathrm{C}, 45^{\circ} \mathrm{C}, 55^{\circ} \mathrm{C}$ as well as $65^{\circ} \mathrm{C}$. All of the isolates showed the longest lag phase when grown at $35^{\circ} \mathrm{C}$ as well as the lowest optical density values Figure 3. When the isolates were grown on $45^{\circ} \mathrm{C}$ Figure 4 the values of OD became higher in comparison with the $\mathrm{OD}$ values when isolates were grown in $35^{\circ} \mathrm{C}$. Isolates ' growth characteristics are found to be different at $55^{\circ} \mathrm{C}$, isolates showed the shortest lag phase and the highest optical density values on $55^{\circ} \mathrm{C}$ Figure 5. The OD values started to reduce again when the isolates were grown in $65^{\circ} \mathrm{C}$ Figure 6 . 


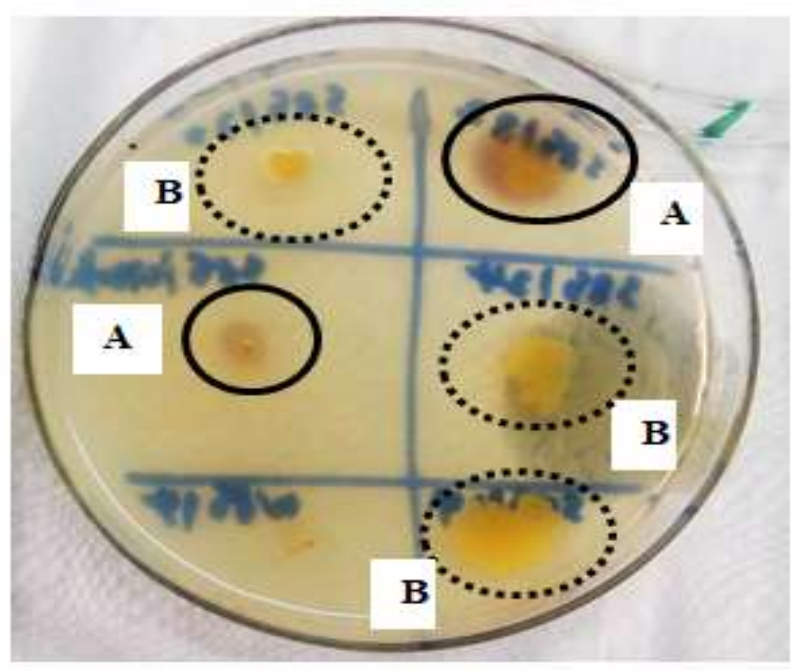

Fig. 2. A. No halo zones showed (-ve cellulase), the circle showed that the colony has the blue color of iodine indicator. B. Zones of hydrolysis shown in the plate (+ve cellulase). The circle showed that the colonv has clear color (no iodine`s blue color showed).

These results indicated that these isolates showed different growth behaviors depending on the temperature during their development. [25] Reported that thermophilic bacteria are categorized as facultative and obligate according to growth temperatures which can varied from $45{ }^{\circ} \mathrm{C}$ to $80{ }^{\circ} \mathrm{C}$. High temperatures are required for the growth of obligate thermophiles, while facultative thermophiles could survive at both low (less than $50^{\circ} \mathrm{C}$ ) and high temperatures. [28] Also conducted a study on the growth curve of thermophilic Bacillus sp. The growth was measured at $75^{\circ} \mathrm{C}$ and the optimal temperature for growth was at $60^{\circ} \mathrm{C}$.

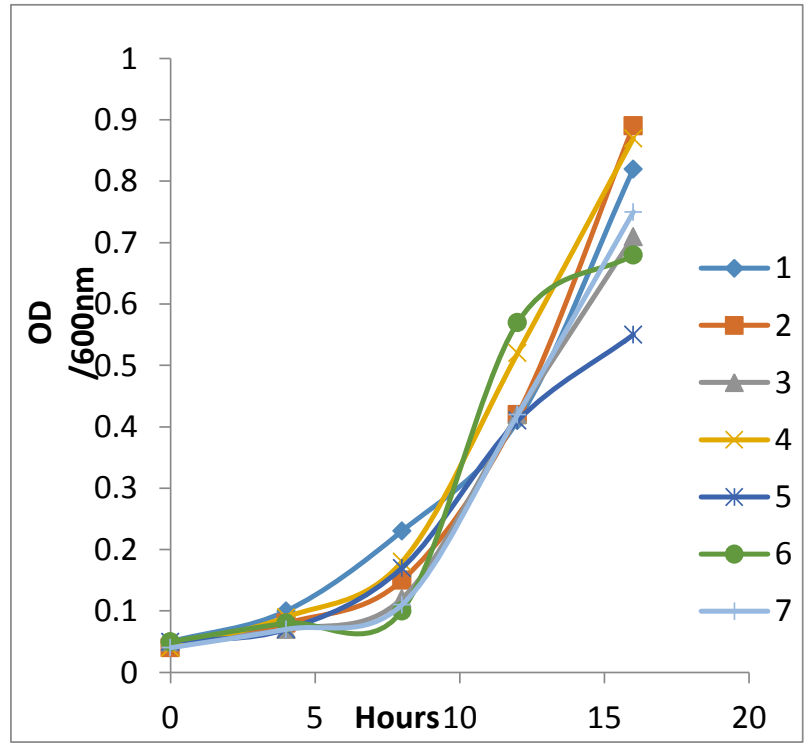

Fig.3. The growth curve of bacteria $\left(35^{\circ} \mathrm{C}\right)$

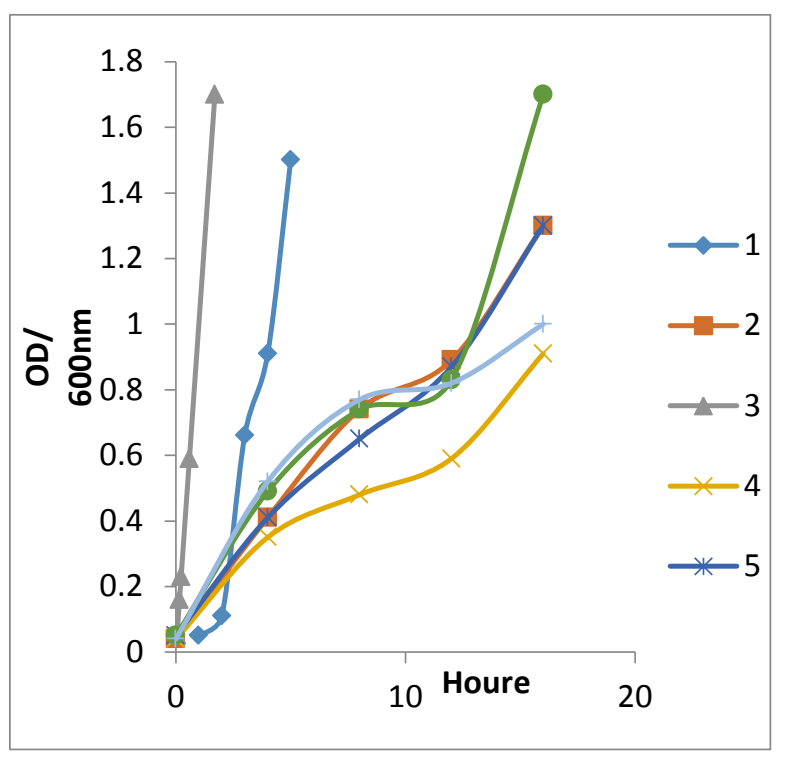

Fig.4. The growth curve of bacteria $\left(45^{\circ} \mathrm{C}\right)$ 


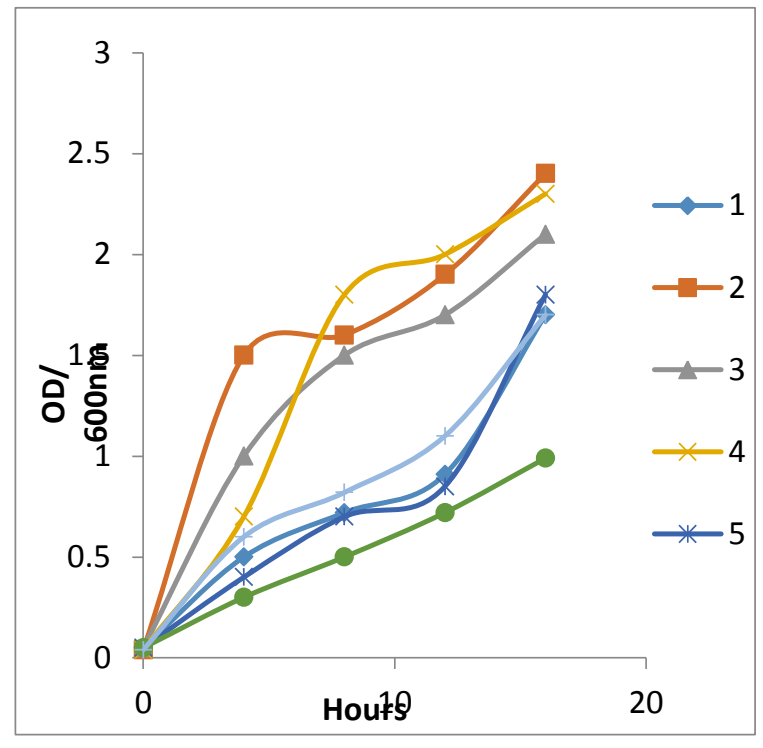

Fig.5. The growth curve of bacteria $\left(55^{\circ} \mathrm{C}\right)$

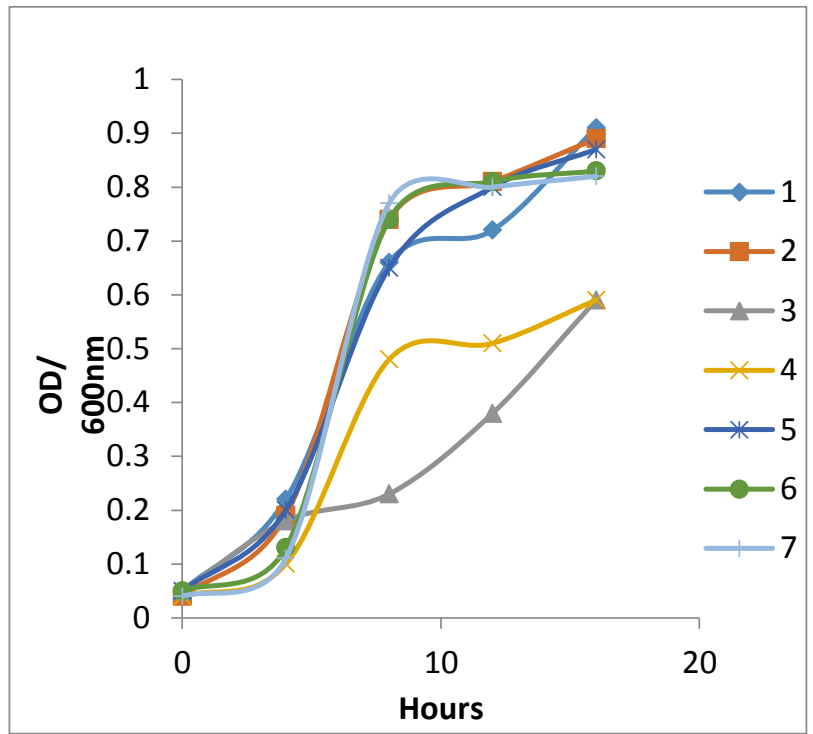

Fig.6. The growth curve of bacteria $\left(65^{\circ} \mathrm{C}\right)$

The Isolates had a broad $\mathrm{pH}$ range for growth from 5.0 to 9.0 with an optimum of 7.0 Figure 7. [8] Also conducted a research discussing the effect of $\mathrm{pH}$ on the growth of thermophilic Bacillus species. They reported that the optimum $\mathrm{pH}$ for growth was 7.0.

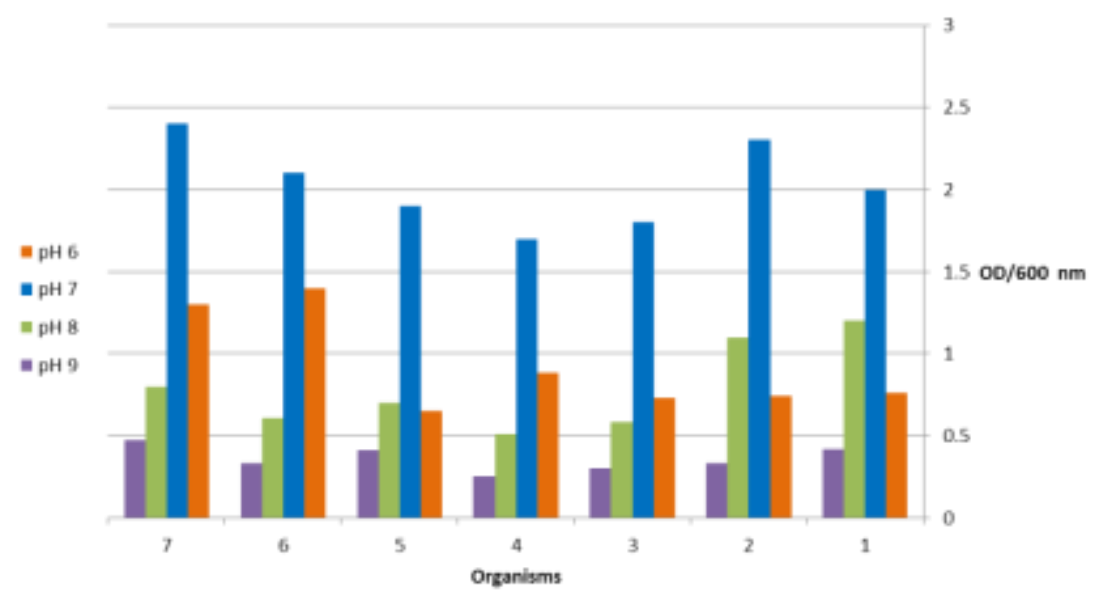

Fig.7. Bacterial growth at different $\mathrm{pH}$ values.

Stability of the enzymes is a key factor when considering whether the operation of biocatalysis will be effective commercially. Enzymes lose part of their function when they undergo heat or intense $\mathrm{pH}$ action [35]. Stability of an enzyme is defined by its ability to maintain its effective structural conformation against destructive conditions, such as rise in temperature [36].

The impact of temperature on both stability and activity of cellulase enzyme was studied in the current work at temperatures range from $35^{\circ} \mathrm{C}$ to $85^{\circ} \mathrm{C}$ (Figure 8). The crude cellulase activity showed the highest value at $55^{\circ} \mathrm{C}$ with $100 \%$ of the enzyme relative activity. The activity started to decline gradually at temperatures higher than $55^{\circ} \mathrm{C}$ until reached to $60 \%$ at $85^{\circ} \mathrm{C}$. In a similar study conducted by [11], they reported that the maximum cellulase activity in Bacillus sp. was at $40^{\circ} \mathrm{C}$. Furthermore, different 
thermophilic bacteria was reported to be producer of thermostable cellulase which does not possess activity for prolonged periods at elevated temperatures (as high as $60^{\circ} \mathrm{C}$ ) [13].

Cellulase enzyme kept $80 \%$ of its stability at $55^{\circ} \mathrm{C}$ and then stability started to decline gradually until reached to $40 \%$ at $85^{\circ} \mathrm{C}$ possibly due to thermal denaturation. On the other hand, researches on thermostability of cellulase enzyme obtained from Geobacillus thermoleovorans T4, reported that with 80 $\%$ of its stability, the crude cellulase's maximum operation was reached at $65^{\circ} \mathrm{C}$. Cellulase stability decreased immediately even with a minor temperature increase above $65^{\circ} \mathrm{C}$, indicating that the enzyme was extremely sensitive to temperatures above $65^{\circ} \mathrm{C}$ [29].

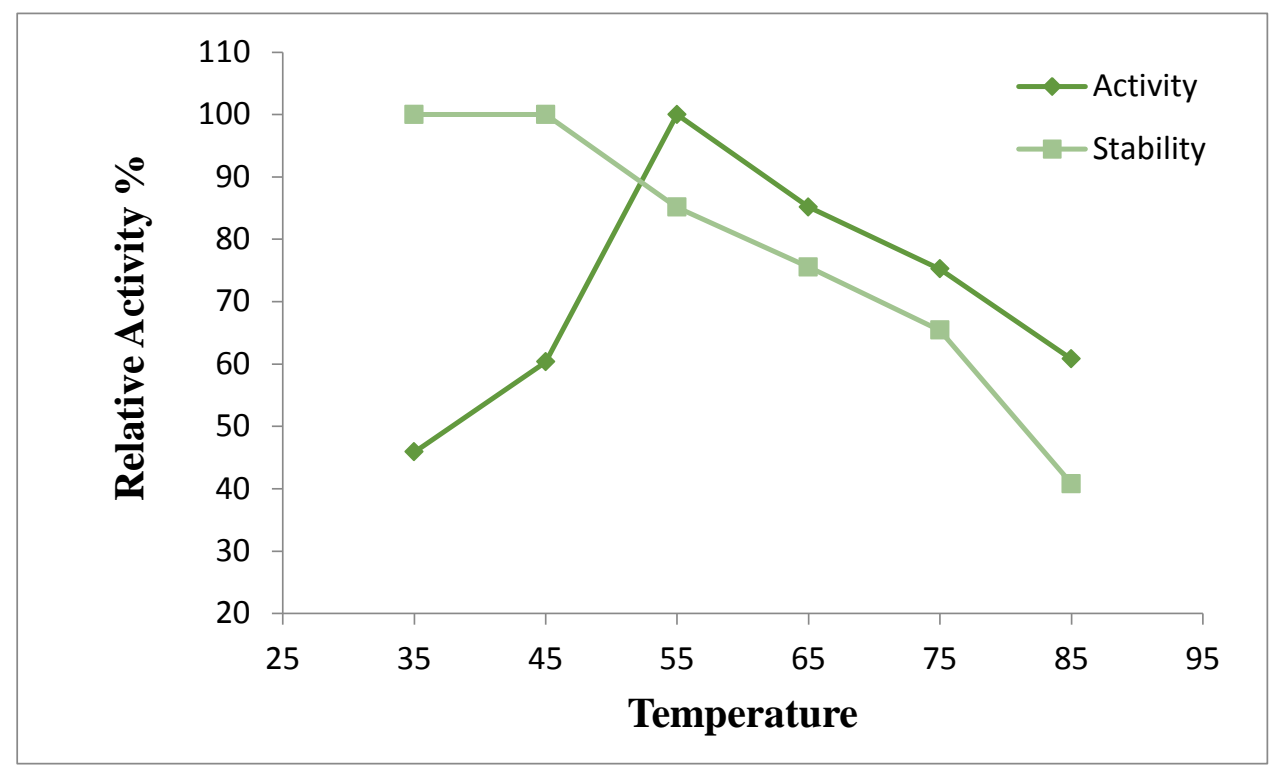

Figure 8 . Impact of temperature on cellulase activity \& stability

The impact of $\mathrm{pH}$ on crude cellulase activity and stability was assessed at $\mathrm{pH}$ levels between 5.0 and 9.0 (Figure 9). The crude cellulase showed the highest activity in phosphate buffer with $100 \%$ at neutral pH 7.0, while the minimum enzyme activity was measured at acid $\mathrm{pH} 5.0$ with $50 \%$ of the enzyme activity. Similar results were observed by [29, 4] who reported the maximum activity of cellulase obtained from Geobacillus sp. T1 at pH 7.0. Another similar study was conducted by [11] where the optimum cellulolytic activity of Bacillus sp. was at $\mathrm{pH}$ 7. On the other hand [16] reported that Geobacillus sp. 70PC53 expressed an optimal cellulase activity at $\mathrm{pH}$ 5.0.

The crude cellulase kept $90 \%$ of its stability when incubated for an hour in $\mathrm{pH} 7$ at $55^{\circ} \mathrm{C}$ and stability declined to be $50 \%$ and $60 \%$ at pH 5 and 9 respectively. Similar results was discussed by [37] who reported that the maximum cellulase stability of Bacillus. sp. DL3 at pH 7. On the other hand [38] reported the maximum cellulase stability of Bacillus sp. HSC7 to be at pH 5.0.

PCR of genomic DNA amplification of the seven isolates revealed a $\sim 1500 \mathrm{bp}$ fragment amplification result using universal 16S rRNA primers (forward $27 \mathrm{~F}$ and reverse 1492R primers). On the basis of BLAST analysis, the thermophilic strains were all found to be similar to those from different species of genus Geobacillus and closely related with the species Geobacillus thermodenitrificans, Geobacillus 
stearothermophilus and Geobacillus jurassicus with similarities $\geq 97 \%$ to known strains (Table 3).

Neighbor-joining evolutionary distance tree based on 16S rRNA gene sequences for isolated strains and selected reference sequences was constructed (Figure 10)

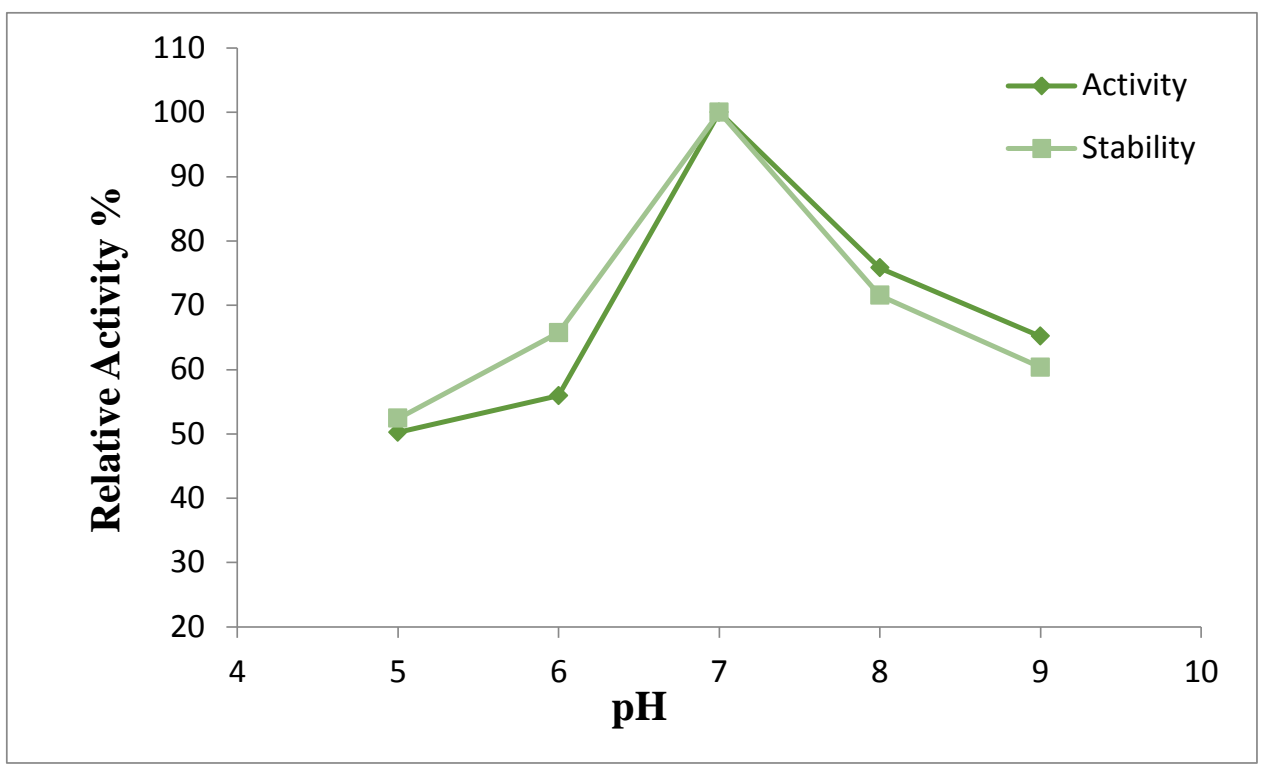

Figure.9. Impact of $\mathrm{pH}$ on cellulase activity and stability.

(Table 3): BLAST analysis of 16S rRNA sequences of the isolated strains.

\begin{tabular}{|c|c|l|}
\hline Geobacillus Isolate & $\begin{array}{c}\text { \% Sequence } \\
\text { similarity }\end{array}$ & \multicolumn{1}{|c|}{ Closest phylogenetic relative } \\
\hline HRS1 & $98.33 \%$ & Geobacillus thermodenitrificans R-32500 (FN428639) \\
\hline HRS12 & $97.53 \%$ & Geobacillus thermodenitrificans R-32615 (FN538995) \\
\hline HRS13 & $97.75 \%$ & Geobacillus thermodenitrificans R-32617(FN428661) \\
\hline HRS14 & $96.66 \%$ & Geobacillus stearothermophilus A1 (KU248350) \\
\hline HRS5 & $96.59 \%$ & Geobacillus stearothermophilus P3 (KU 248348) \\
\hline HRS6 & $96.95 \%$ & Geobacillus stearothermophilus IFO 12550 ( NR_040794) \\
\hline HRS7 & $96.81 \%$ & Geobacillus jurassicus MK7(MT126376) \\
\hline
\end{tabular}

As candidates for industrial application of thermostable hydrolases, the ability of bacilli species should be recognized. The number of thermophilic bacilli species belonging to the Bacillus sp., Geobacillus sp. and Anoxybacillus sp. has been cultured from various geothermal hot springs and identified as thermostable cellulase producers [19, 7]. A study by [27] stated that Geobacillus toebii PS4 and Geobacillus thermoleovorans PW13 collected from Himachal Pradesh's Tattapani hot spring in India gave optimal 80$90^{\circ} \mathrm{C}$ and 6.0-8.0 $\mathrm{pH}$ cellulase activity. The ability to grow at elevated temperatures makes Geobacillus sp. attractive agents in the applications of biotechnology. These bacteria could be producers of different enzymes that are considered as thermostable enzymes [29, 2, 22]. 


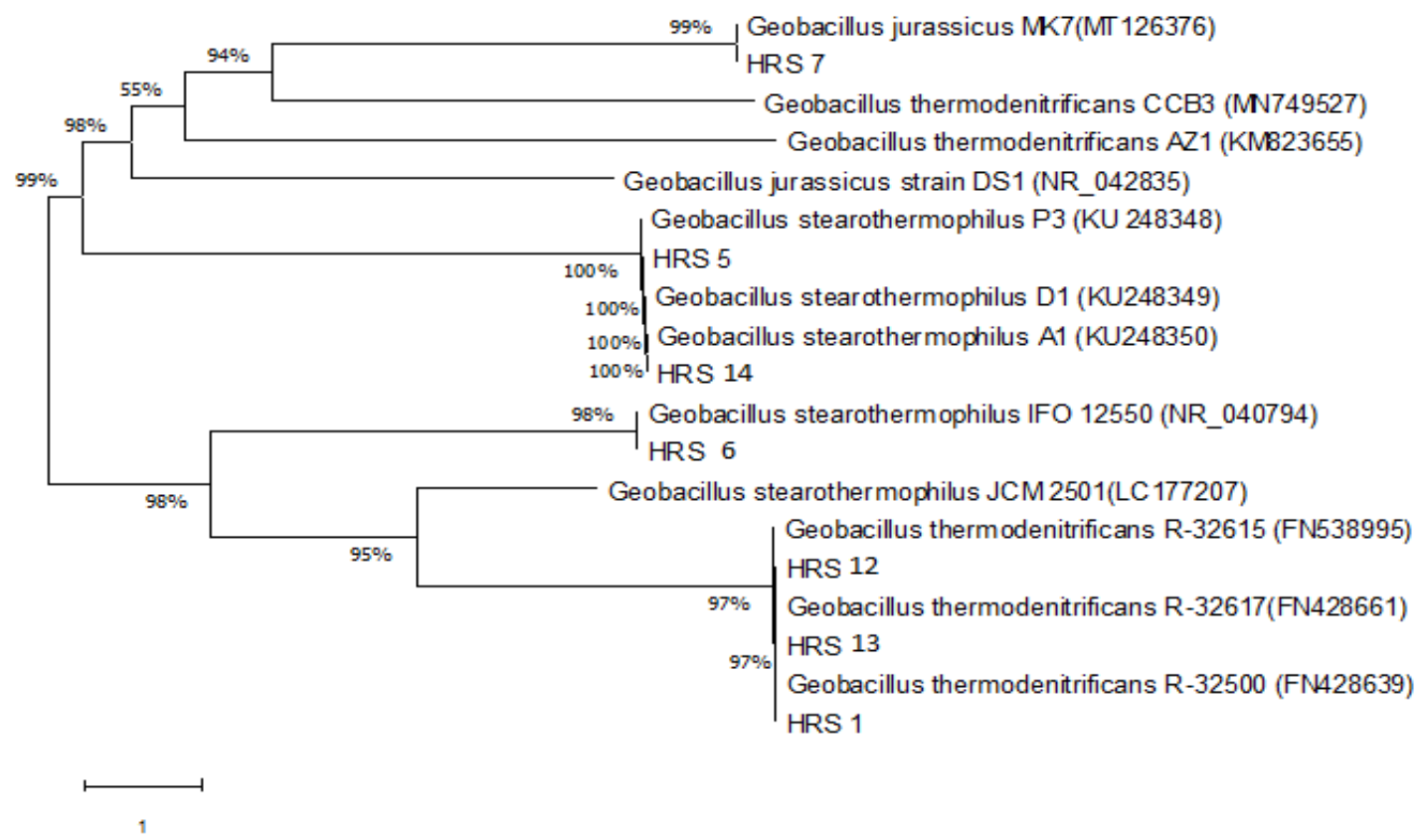

Figure.10. Phylogenetic tree of the identified strains.

\section{CONCLUSION \& RECOMMENDATIONS}

The thermophiles which studied through the current work have the ability to produce useful thermostable cellulase of industrial significance. Ras-sedr's hot spring considered a prospective source of economically significant microorganisms which needs more studies through further researches.

\section{REFERENCES}

[1] Bartlett, J.M. and Stirling, D. A short history of the polymerase chain reaction. Methods Mol. Biol, 226, 3-6, 2003.

[2] Abdel-Fattah, Y.R., El-Helow, E.R., Ghanem, K.M. and Lotfy, W. A. Application of factorial designs for optimization of avicelase production by a thermophilic Geobacillus isolate. Res $J$ Microbiol, 2, 13-23, 2007.

[3] Abdelnasser, S. S. I. and Ahmed, I. E. Isolation and identification of new cellulase producing thermophilic bacteria from an Egyptian hot springs and some properties of the crude enzyme. Australian Journal of Basic and Applied Sciences, 4, 473-478, 2007.

[4] Assareh, R., Shahbani Zahiri, H., Akbari Noghabi, K., Aminzadeh, S.and Bakhshi Khaniki G. Characterization of the newly isolated Geobacillus sp. T1, the efficient cellulase-producer on untreated barley and wheat straws. Bioresour Technol., 120, 99-105, 2012.

[5] Cavaco-Paulo, A. Mechanism of cellulase action in textile processes. Carbohyd Polym, 37, 273277, 1998.

[6] Cheesbrough, M.,. District Laboratory Practice in Tropical Countries. Cambridge University Press, Cambridge, UK., (2006) 2nd Edn.

[7] DeCastro, M. E., Rodríguez-Belmonte, E. and González-Siso, M.I. Metagenomics of Thermophiles with a Focus on Discovery of Novel Thermozymes. Front. Microbiol., 7, 1521-1530, 2016.

[8] DeSouza., A. N and Martins., M. L. L. Isolation, properties and kinetics of growth of a thermophilic bacillus. Braz. J. Microbiol., 32, 271-275, 2001. 
[9] Fawole, M.O. and B.A. Oso. Characterization of Bacteria: Laboratory Manual of Microbiology. 4th Edn., Spectrum Book Ltd., Ibadan, Nigeria, 24-33, 2004.

[10] Harely, J. P. and Prescott, L. M. Laboratory Excersizes in Microbiology. MacGraw-Hill, New York. 2002. 5th Edn.

[11] Immanuel, G., Dhanusa, R., Prema ,P. and Palavesam A. Effect of different growth parameters on endoglucanase enzyme activity by bacteria isolated from coir retting effluents of estuarine environment. Int. J. Environ. Sci. Tech., 3, 25-34, 2006.

[12] Islam, F and Roy, N . Screening, purification and characterization of cellulase from cellulase producing bacteria in molasses BMC Res, 11, 434:445, 2018.

[13] Liang, Y., Feng. Z., Yesuf, J. and Blackbure, J. Optimization of growth medium and enzyme assay conditions for crude cellulase produced by a novel thermophilic and cellulolytic bacterium, Anoxybacillus sp. 527. Appl Biochem Biotechnol., 160, 1841-1852, 2010.

[14] Maki, L., Miranda, B., Michael, L., Kam, T. and Qin, W. Characterization of some efficient cellulase producing bacteria isolated from paper mill sludges and organic fertilizers. Int. J. Biochem. Mol. Biol., 2, 146-154, 2011.

[15] Chang,C.Ng.C and Wang.C. Activity of cellulase from Thermoactinomycetes and Bacillus spp. isolated from brassica waste compost. Sci. Agric. 66, 304-308, 2009.

[16] Ng, I.S., Li, C.W., Yeh. Y.F., Chen, P.T., Chir, J.L., Ma, C. H, Yu, S.M., Ho, T.H and Tong, C. G. A novel endo-glucanase from the thermophilic bacterium Geobacillus sp. $70 \mathrm{PC} 53$ with high activity and stability over a broad range of temperatures. Extremophiles., 13, 425-435, 2009.

[17] Norashirene, M. J., Zakiah, Y., Nurdiana, S., Nur Hilwani, I., Siti Khairiyah, M. H. and Muhamad Arif , M. JIdentification of Cellulose-Hydrolytic Thermophiles Isolated from Sg. Klah Hot Spring Based On 16S rDNA Gene Sequence. Int. J. Agric. Eng , 8, 1041-1044, 2014.

[18] Ponnambalam, A.S., Deepthi, R.S. and Ghosh, A.RQualitative display and measurement of enzyme activity of isolated cellulolytic bacteria. Biotechnol. Bioinf. Bioeng., 1, 33-37, 2011.

[19] Raddadi, N., Cherif, A., Daffonchio, D., Neifar, M. and Fava. F. Biotechnological applications of extremophiles, extremozymes and extremolytes. Appl. Microbiol. Biotechnol., 19, 7907-7913, 2015.

[20] Rahman, R., Leow, T.C. and Salleh, A.B. Geobacillus zalihae sp. nov., a thermophilic lipolytic bacterium isolated from palm oil mill effluent in Malaysia. BMC Microbiol, 7, 77-88, 2007.

[21] Rainey, F.A., Fritze, D and Stackebrandt, E. The phylogenetic diversity of thermophilic members of the genus Bacillus as revealed by 16S rDNA analysis. FEMS Microbiol. Lett, 115, 205-212, 1994.

[22] Rastogi, G., Muppidi, G. L., Gurram, R.N., Adhikari. A., Bischoff, K.M. and Hughes, S.R. Isolation and characterization of cellulose-degrading bacteria from the deep subsurface of the Homestake gold mine, Lead, South Dakota, USA. J Ind Microbiol Biotechnol , 36, 585-598, 2009.

[23] Reyes, J. L., Rodrigo, M. J., Colmenero-Flores, J. M., Gil, J. V., Garay-Arroyo, A., Campos, F. Hydrophilins from distant organisms can protect enzymatic activities from water limitation effects in vitro. Plant Cell Environ, 28, 709-718, 2005.

[24] Satyanarayana, T., Raghukumar, C., Shivaji, S. Extremophilic microbes: diversity and perspectives. Curr. Sci, 89, 78-90, 2005.

[25] Sen, S.K., Satpathy, S and Rao, G.T.V. Characterization of hot water spring source isolated clones of bacteria and their industrial applicability. Int J Chem Res. 2, 1-7, 2010.

[26] Shah, A.R. and Madamwar, D. Xylanase production under solid-state fermentation and its characterization by an isolated strain of Aspergillus foetidus in India. World J Microbiol Biotechnol., 21, 233-243,2005.

[27] Sharma, P., Gupta, S., Sourirajan, A. and Dev, K. Characterization of extracellular thermophillic cellulase from thermophilic Geobacillus sp. isolated from Tattapani Hot spring of Himachal Pradesh, India. Int J Adv Biotech Res., 3, 433-442, 2015. 
[28] Shimura M., Kimbara K., Nagato H. and Hatta T. Isolation and characterization of a thermophilic Bacillus sp JF8 capable of degrading polychlorinated byphenyls and naphthalene. FEMS Microbiol. Lett., 178, 87-93, 1999.

[29] Tai, S.K., Lin, H.P.P., Kuo, J. and Liu, J.K. Isolation and characterization of a cellulolytic Geobacillus thermoleovorans T4 strain from sugar refinery wastewater. Extremophiles, 8, 345-349, 2004.

[30] Vieille, C. and Zeikus, G.J. Hyperthermophilic enzymes: sources, uses, and molecular mechanisms for thermostability. Microbiol. Mol. Biol, 65, 1-43, 2001.

[31] Vijayaraghavan P. and Vincent S.G.P. Cow dung as a novel, inexpensive substrate for the production of a halo-tolerant alkaline protease by Halomonas sp. PV1 for eco-friendly applications. Biochem. Engg. J., 69, 57-60, 2012.

[32] Lupicka, T. Krecidio,L and Krecidio, M. The Comparison of Cellulolytic Activity of The Modified Soil Treated With Roundup. CHEM DIDACT ECOL METROL. 21, 133-139, 2016.

[33] Sethi. S, Datta A, Gupta BL, Gupta S. Optimization of cellulase production from bacteria isolated from soil. Int Scholarly Res Notices. Biotechnol. 8, 125-132, 2013.

[34] Li ,Y. Wang, J. Liu,X. and Zhang, S. Towards a molecular understanding of cellulose dissolution in ionic liquids: anion/cation effect, synergistic mechanism and physicochemical aspects. Chem. Sci., 9, 4027-4043, 2018.

[35] Longo, M. A. and Combes, D. Analysis of the thermal deactivation kinetics of $\alpha$-chymotrypsin modified by chemoenzymatic glycosylation. Biotechnol. Prog..15, 135-140, 1998.

[36] Yeoman, C. Han, D. Y. Dodd, C. Schroeder, M.and Cann, I. K.O Thermostable Enzymes as Biocatalysts in the Biofuel Industry. ADV APPL MICROBIOL.70, 1-55, 2010.

[37] Li, W. Zhang, W.W. Yang, M.M.and Chen, Y.L. Cloning of the Thermostable Cellulase Gene from Newly Isolated Bacillus subtilis and Its Expression in Escherichia coli. Mol. Biotechnol. 40, 195201, 2008.

[38] Azadian, F. Badoei-dalfard, A. Namaki-Shoushtari, A. Karami, Z. Hassanshahian, M. Production and characterization of an acido-thermophilic, organic solvent stable cellulase from Bacillus sonorensis HSC7 by conversion of lignocellulosic wastes. Journal of Genetic Engineering and Biotechnology 15, 187-196, 2017. 